\title{
MENTAL HEALTH AMBULATORY: WEAKNESSES POINTED OUT BY PROFESSIONALS ${ }^{1}$
}

\author{
Marcelle Paiano², Mariluci Alves Maftum³, Maria do Carmo Lourenço Haddad ${ }^{4}$, Sonia Silva Marcon ${ }^{5}$
}

\footnotetext{
${ }^{1}$ Article extracted from the dissertation - Fourth generation evaluation process in a mental health ambulatory: professionals' perspective, presented at the Graduate Program in Nursing at the Universidade Estadual de Maringá (UEM), in 2013.

2 Ph.D. in Nursing, Graduate Program in Nursing, UEM. Maringá, Paraná, Brazil. E-mail: marcellepaiano@hotmail.com

${ }^{3}$ Ph.D. in Nursing. Professor, Universidade Federal do Paraná. Maringá, Paraná, Brazil. E-mail: maftum@ufpr.br

${ }^{4}$ Ph.D. in Fundamental Nursing. Professor, Nursing Department, Universidade Estadual de Londrina. Londrina, Paraná, Brazil. E-mail: carmohaddad@gmail.com

${ }^{5}$ Ph.D. in Nursing Philosophy. Professor of the Graduate Program in Nursing, UEM. Maringá, Paraná, Brazil. E-mail: soniasilva. marcon@gmail.com
}

\begin{abstract}
The aim of this study was to identify the weaknesses of the mental health ambulatory service from the professionals' perspective. This was a qualitative study, developed by the Fourth Generation Evaluation method. Data were collected during February and March 2013 with the use of non-participant observation, individual opened interviews and group technique for the negotiation session. The informants were 12 working professionals at the ambulatory. The results pointed out weaknesses in the organizational structure of the healthcare network in mental health, especially regarding accessibility, physical structure and the presence of extensive waiting list for care. Regarding human resources, issues included: ignorance of the operation of the mental health network and of the activities performed, medical turnover, deficiency in training and continuous education and professional devaluation. It is necessary to reflect on the real role of ambulatories within the mental health network and its effectiveness in providing care.
\end{abstract}

DESCRIPTORS: Health evaluation. Mental health services. Mental health. Nursing.

\section{AMBULATÓRIO DE SAÚDE MENTAL: FRAGILIDADES APONTADAS POR PROFISSIONAIS}

RESUMO: O objetivo do estudo foi identificar as fragilidades de um serviço ambulatorial de saúde mental na perspectiva dos profissionais. Estudo qualitativo, desenvolvido pelo método da Avaliação de Quarta Geração. Os dados foram coletados em fevereiro e março de 2013 , com o uso da observação não participante, entrevista aberta individual e técnica grupal para a sessão de negociação. Os informantes foram 12 profissionais atuantes no ambulatório. Os resultados apontaram fragilidades na estrutura organizacional da rede de assistência em saúde mental, especialmente na forma de acesso, estrutura física e a presença de extensa fila por atendimento. Referente aos recursos humanos incluem-se: desconhecimento do funcionamento da rede de saúde mental e das atividades realizadas, rotatividade médica, deficiência na capacitação e educação permanente e desvalorização profissional. Faz-se necessário refletir sobre a real função dos ambulatórios dentro da rede de saúde mental e sua efetividade na prestação de cuidados.

DESCRITORES: Avaliação em saúde. Serviços de saúde mental. Saúde mental. Enfermagem.

\section{AMBULATORIO DE SALUD MENTAL: DEBILIDADES SEÑALADAS POR PROFESIONALES}

RESUMEN: El objetivo del estudio fue identificar las debilidades de un servicio ambulatorio de salud mental en la perspectiva de los profesionales. Estudio cualitativo, de tipo estudio de caso, desarrollado por medio de la evaluación de Cuarta Generación. Los datos fueron recolectados en febrero y marzo de 2013 con el uso de la observación no participante, entrevista abierta individual, técnica grupal para la fase de negociación. Los informantes fueron 12 profesionales. Los resultados señalaron fragilidades en la estructura organizacional de la red de asistencia en Salud mental especialmente: forma de acceso, estructura física y la presencia de filas extensas. En los recursos humanos: desconocimiento del funcionamiento de la red de salud mental, de las actividades realizadas, rotatividad médica, deficiencia en la capacitación y educación permanente, desvalorización profesional. Las fragilidades identificadas señalan la necesidad de reflexión sobre la función de los ambulatorios y su eficacia en la prestación de cuidados.

DESCRIPTORES: Evaluación en salud. Servicios de salud mental. Salud mental. Enfermería. 


\section{INTRODUCTION}

In Brazil, the Psychiatric Reform, which was marked by the progressive extinction of asylums and the inclusion and social rehabilitation of the person in psychic suffering as a guiding axis of professionals' actions, is currently underway. According to this reform, states and cities should implement a fair, inclusive, extramural and community based mental health policy. For this purpose, the organization of a network of integral attention to mental health is needed in order to meet the needs of care, promote social integration and qualify the existence of these people.

One of the first regulations for the organization of mental health services divided the assistance into two large groups: the hospital treatment and the ambulatory treatment. The hospital treatment comprised the admission and the semi-admission, and the ambulatory treatment comprised the outpatient itself, the centers of psychosocial care (Centros de Atenção Psicossocial, CAPS) and the nuclei of psychosocial care (Núcleos de Atenção Pessoal, NAPS). ${ }^{2}$

The ambulatories, attention points of the mental health assistance as well as within the framework of the psychiatric reform, should encompass the service conducted in the basic health units (Unidades Básicas de Saúde, UBS), health centers and in specialized ambulatories inserted or not in polyclinics. The developed activities should concentrate on individual and group services, in home care and in community activities, especially in the area of reference. $^{2}$

However, the mental health ambulatories keep reproducing the asylum model somehow, because they focused their activities in the specialty and adopted an assistance model based on the psychiatric knowledge. Therefore, even though they are inserted into a welfare policy based on the principles of the Psychiatric Reform and of the Unified Health System (SUS), and are reference to numerous consultations in Psychiatry and Psychology, these ambulatories feature a few problems, including the low resolution and low articulation with the mental health network, which favors the crisis-hospitalization-high-crisis-re-hospitalization cycle and the chronicity of treated cases. ${ }^{3}$

Concomitantly, the absence of a welfare policy that delimits the operation of the ambulatories, associated with the lack of training and updating of professionals, to the difficulty in producing actions in an integrated form with other points of service network, in building circulation and exit doors in the network, and enabling people suffering from mental disorders new forms of relationship and social skills in the community, make the role of these services in the current scenario of the Psychiatric Reform be questioned..$^{3-7}$

In this context, to find out about the opinion of working professionals in the Mental Health Ambulatory about the care provided to people with mental disorders is fundamental towards the understanding of the role of these services in the Psychosocial Care Network (Rede de Atenção Psicossocial, RAPS). Thus, from the presentation above, it was delimited as the objective of the study the identification of the weaknesses of the ambulatory mental health service from the perspective of its professionals.

\section{METHOD}

This was a qualitative study, in which the Fourth Generation Evaluation was adopted as methodological strategy. This was an alternative evaluation proposal, based on the constructivist paradigm and which has as its main characteristics the fact of being responsive, flexible and adopting the hermeneutical-dialectic approach in its conduction. ${ }^{8}$ Thus, it was responsive because the evaluator is responsible for what emerges from the evaluation. In addition, it involved an interactive and negotiated process between the researcher and the interest groups, that is, people who have any interest in the performance, the product or the impact of the object of the evaluation, for being somehow involved or being potentially affected by the service and by the eventual consequences of the evaluation process. Therefore, their claims, concerns, and issues (reinvidicações, preocupações e questões, RPQ) related to the object under evaluation should determine the information to be raised. ${ }^{8}$

The study was carried out in the mental health ambulatory of a city in the Northwest of Paraná, known as Integrated Mental Health Center (Centro Integrado de Saúde Mental, CISAM).

The assistance network in mental health in this city is comprised of: a psychiatric hospital affiliated to SUS, with 240 beds and reference for three Health Regionals (11th, 13th and 15th Health Regionals, totaling 67 cities): a CISAM (established in 1994), an Alcohol and drugs Psychosocial Care Center (CAPS-ad) (established in 2002); a Public Psychiatric Emergency (established in 2003); a CAPS II (established in 2004); a children's CAPS (established in 2012); and three Therapeutic Homes (two male and one female, established in 2006, 2009 and 2011). 
At the CISAM, services are not carried out by free demand. The referrals may originate from the psychiatric emergency, the UBSs, psychiatric hospital, therapeutic residence and CAPS II. Services are scheduled and consist of individualized assistance and consultations in the fields of psychology, psychiatry, nursing, pharmacy, occupational therapy and social work, and aims in providing continuity to the hospital treatment, in carrying out evaluations and periodic controls, in establishing diagnosis and therapeutic plans. In this service there are also therapeutic workshops, waiting room groups and information groups, assistance to smokers, parents' guidance, individual and/or group psychotherapy for children, teenagers and adults, care and guidance for the family regarding the illness, the treatment and their participation in aid groups and, moreover, the dispensation of psychotropic medication. ${ }^{9}$

The staff at CISAM is comprised of three nurses, seven psychologists, one social worker, two psychiatrists, one pharmacist, two pharmacy assistants, four assistant-nurses and a director, all hired for 40 hours a week, via public tender. There are also three Psychiatry residents in the service, working 20 hours a week.

It is important to highlight that, according to the Psychiatric Reform in progress, the CISAM will no longer serve on ambulatory mode and will turn into CAPS III, with 24-hour service, including holidays and weekends as a mental health clinical back up. However, there is still no prediction for the implementation of this change. ${ }^{9}$

Data were collected during the months of March and April 2013, through observation of the service operation, and through semi-structured interviews with the members of the interest group, that is, the professionals working there. There was a total of 80 hours of observation (eight hours a day for two weeks) when 12 professionals were interviewed.

All activities carried out in CISAM constituted object of observation and were recorded in field notes in descriptive form. These observations allowed for the identification of the characteristics of the service role, facilitating the understanding of the demands, concerns and issues of the interest group and the professional's choice on how to start the hermeneutical-dialectic circle.

The hermeneutical-dialectic circle was the route used to ensure the constructive and participatory character of this type of evaluation. It was her- meneutic because of its interpretative character and dialectic because it implied comparison and contrast of different points of view, aiming at high level of synthesis. ${ }^{8}$ The objective was to reach consensus, when possible; and when not, to expose and clarify the different perceptions. Therefore, besides the interviews with people indicated by the respondents themselves, the negotiation session was essential.

To initiate the hermeneutical-dialectic circle, an open interview was held with the first respondent (R1), chosen by the coordinator of the service. The remaining respondents were indicated by the respondents themselves. The conclusion of the circle took place when the indications of professionals began to be repeated, ending with 12 of the 23 professionals active in service.

The main issues presented initially to all respondents were: Talk about the assistance during work; What do you appreciate and what do you not appreciate in patient care in this service; In your opinion, what can contribute for better functioning of the service? New questions were incorporated, according to the methodological frame of reference used in a concomitant process of analysis and data collection. Thus, R1 was invited to present his personal impressions in relation to the three guiding questions and the analysis of this interview allowed the identification of some core aspects and the formulation of the first construction (C1) about the object under evaluation.

The same initial questions were presented to $\mathrm{R} 2$, added to the construction formulated by the interview with R1. As a result, the interview of $\mathrm{R} 2$ produced information related not only to their personal impressions on the initial issues, but also to the opinions about the construction of R1.

The analysis of the second interview produced the second construction (C2) and this proved to be a more complete and comprehensive one, and thus followed until the last interview. From the second interviewed on, all of the others were invited to answer the initial questions and give their opinion about the constructions that were being implemented, starting from the analysis of the previous interviews of each participant in the study.

Negotiation was carried out at the end of the circle. At this stage, information collected through all the interviews was organized, summarized and presented, so that all participants had access to the entire material and, as a group, were able to decide on what could or could not remain as a result of the study. Therefore, a meeting was previously 
scheduled at agreed time with coordinator of the service, and all participants of the circle were invited to participate, when the provisional result of the analysis of the interviews was presented. Discussions during this meeting were also recorded and used as research data.

Data were analyzed using the Constant Comparative Method, which allowed it to be analyzed concomitantly with its collection. This method included two steps: the identification of the information units and the categorization. The information units are sentences or paragraphs obtained in the empirical material, recorded in a comprehensible way to any reader, not only the researcher. ${ }^{8}$

After the identification of information units, the same contents were unified in temporary categories, seeking to establish an internal consistency in order to, later, from the negotiation on, build the final categories. ${ }^{8}$ Thus, at the end of the negotiation, the questions raised were regrouped, providing the identification of two major core themes: Organizational weaknesses of the network; and Weaknesses related to human resources of the mental health network.

The development of the study followed the procedures established by the National Health Council Resolution 466/2012, and its project was approved by the Standing Research Ethics Committee (CAAE 10277812.6.0000.0104). To maintain anonymity, workers were identified with the letter " $\mathrm{P}$ " for participants, followed by a sequence number corresponding to the order on how the interviews took place.

\section{RESULTS AND DISCUSSION}

Data were grouped into two categories and demonstrate the weaknesses related to the organizational form of the ambulatory services and other services, and the professionals' difficulties in assisting the mental health area.

\section{Organizational weaknesses of the mental health network}

Among the organizational weaknesses pointed out, the access to ambulatory services was mentioned, which is based upon UBSs' referrals. This form of service does not supply the demand, which creates a long waiting line, because there is only one ambulatory in the city providing psychiatric care: initially the patient comes referred from UBS, where he goes through a waiting line in the post, then when there is a vacancy we call from the center and they book the consultation [...] the waiting line takes more than three months [...] (P3).

The patient has the option to speed up the process and proceed with the consultation by waiting for a vacancy left in the ambulatory.

[...] there are patients that have been waiting for months [...] then when the day comes, they forget to come, this vacancy will remain open [...] the doctor is there to see the patient, and the patient who missed will be placed at the back of the line again. [...] So, there are those who come and just wait, knowing they run the risk of returning home without the consultation [...] (P4).

In the city studied, the UBS is one of the most requested entry doors for mental health care by users. Depending on the approach at this level of service, the patient may receive a referral to the ambulatory or have the problem solved right away. Therefore, the service with a psychiatrist depends on the criteria of each professional that works at UBS and their experience in mental health, interfering directly in the size of the waiting line.

Findings on this issue confirmed the ones of a study carried out in Santa Maria-RS, with health services coordinators, noting that the substitute services (CAPS and municipal ambulatory) find themselves strangled due to a high number of referrals. Thus, the evidence confirms that the healthcare, in the medium and high complexity specialties and diagnostic support, is, in general, a place of health system strangulation. ${ }^{10}$

Due to the high demand for mental health services, and the resulting waiting line, this demand ends up returning to the UBS that constitutes the only means of available access. Therefore, a repressed demand is formed, returning in search for care. This is a difficulty faced by professionals, but mostly by users, which, by not having their needs met, transit through the system. Thus, there is an overload of service due to the absence of a resolution, which, in turn, adds to the suffering of users and families. ${ }^{10}$

In 2010, the guidelines for structuring the Health Care Networks were published, as a strategy to overcome the fragmentation of attention and management in health areas. Some tools were included in it, enabling to vertically integrate the service points and conform the RAS. One of these tools is the Care Line (Linha de cuidado, LC), which consists of a form of articulation of resources and of practices of health production, aiming at the coordination along the continuum care, through the 
agreement and the connectivity of roles and tasks of the different points of attention. ${ }^{11}$

The implementation of the care line should start from basic units that are responsible for carrying out the coordination of care and the management of the network, focusing on various aspects: ensuring human and material resources, integration and mutual engagement of health units, interaction between teams, processes of permanent education, management of commitments agreed upon, amongst others. ${ }^{11}$

The isolation of mental health services was also mentioned by professionals as a weakness, either by the lack of communication with the other network devices, or because its professionals participate in the least number of courses offered by the Health Secretariat or even simply because they are hampered against working in this type of service. Another colleague from CAPS and I, it is as if we lived in a service that is isolated from the rest of the network [...] we were isolated! The lady from the children's CAPS and the other two from the city hospital have the same complaints (P4).

This is how it happened; I was from the Family Health Program. Then they sent me to the CAPS. I don't like it, I got there, like a scared kitty, because I was afraid of psychiatric patients (P8).

It is quite isolated, indeed, from the rest of the network, so much so that, I had no idea of how the ambulatory worked, much less how the CAPS worked and, sometimes, we did not even make the referral, because we thought it was going to take too long (P11).

One of the possibilities to overcome the network's disarticulation and attempt to reduce the prejudice that surrounds these services is the construction of a network of mental health that is extramural, solid, consistent, co-responsible for the development of health actions together with the community, able to extend the potential of good practices "at the time of the crisis/outbreak" in the out-patient treatment services; to promote training, support and supervision through the matrix support and to invest in the training of health workers - both academic and continued education. ${ }^{12}$ This horizontal articulation enables assistance to users in a more integrated way, contributing to the (de)construction of segregation and confinement of people with mental disorders. ${ }^{13}$

The high number of assistance (an average of 3,000 per month, involving the dispensation of medication, psychological and psychiatric consultation), was also pointed out by the respondents, including that the fact there is only the ambulatory to meet the entire demand of the city in the area of mental health compromises the quality of the service.

The ambulatory is no different from other sectors; the demand is higher than the capacity of the service offered, generating some strangling in the flow of the service. Much has already been done, however even more could and should be done (P10).

I think that volume is a very serious issue [...] you cannot do a quick service, because the patient is too complex (P4).

There is excessive demand because people who look for care aim at an immediate solution to a chronic condition that should already have been detected, and even treated, back at primary health attention. However, it is noted that this level of assistance has presented itself as a very incipient entry door, that is, marked by low resolution, especially in mental health.

For this reason, users seeking primary care assistance are often referred to other network points (CAPS and ambulatory), as if this level of assistance could not be responsible for mental health disorders, disregarding the person behind the illness. ${ }^{11}$

Therefore, despite the striking demand for mental health care in primary health care, considering that the Family Health Strategy (ESF) is the first contact that people with mental disorders have available, their teams express difficulties in the identification and follow-up of those people in the community. ${ }^{12}$

Also, available indicators in the municipal, regional and national information systems, contribute only for information about hospitalizations in psychiatric hospitals or hospitalizations for mental disorder in general hospitals and of service in CAPS, that is, there are no indicators providing visibility to the demand or the service done in primary health care. ${ }^{12}$ In this sense, the existence of an indicator at this level of attention could contribute to the detection and monitoring of users on their own territory.

The physical structure of the service was also mentioned by the interviewees as an extensive setback to meet patients with quality and comfort, in addition to being an obstacle to the development of actions envisaged by the Ministry of Health, such as educational groups, waiting rooms, services for family and other activities requiring physical space availability.

I would really like to develop audiovisual activities, for patients; I have the material, but I don't have the resources, for instance, I want to give a lecture, but it's 
not possible because of the space here, I'm going to speak there, it will disturb the reception (P4).

The lack of the mentioned external area and internal space of the ambulatory, in order to develop group activities, also appears in another study that reports a similar situation at a CAPS; an old ambulatory which worked in a big building, with many offices for individual services and few appropriate rooms for group activities. ${ }^{14}$

An important aspect, involving the physical structure, relates to the dispensation of psychotropic drugs, because they are given only in CISAM and in the CAPSad, so there is quite a large demand of patients and families who seek the services only for that purpose. Thus, the fact that the pharmacy is located next to the reception hampers the patients' path and families that are grouped in the waiting room waiting for both the dispensation of medication and medical and psychological examinations, and also nursing care and the social worker's services.

The pharmacy near the reception is always full because I think that one should not put the two things together, I think that it should be separated: psychiatric and psychological services and pharmacy in different places, because many times people come and they don't know that service is happening there, so they talk loudly without a clue about it (P3).

A big, huge mistake was to take advantage of the ambulatory pharmacy to meet the demand of UBS, Municipal Hospital, Psychiatric Hospital, nursing homes, hostels, retirement homes, among other numerous institutions (P10).

Attention to patients in ambulatories must include the individual serice (consultation, psychotherapy, and others); group service (operating group, therapeutic, social therapeutic activities, mentoring groups, waiting room activities, educational activities on health); home visits by midlevel or higher professional level and community activities, especially in the area of health service reference. $^{2}$

Thus, issues highlighted during the session of negotiation with the professionals were mainly related to the organizational structure of the ambulatory that must be improved, for example, by the users' difficulty to access the service, the deficiency in physical structure and fragmentation of mental health services.

Therefore, from observation in general, the organization between the mental health services follows a fragmented concept of care. For each stage in which the user is found, there is a service, and each one deals with an object itself. There is, therefore, a policy that does not anticipate effective articulation or partnership establishment. ${ }^{15}$

\section{Weaknesses related to human resources of the mental health network}

The ignorance of the ambulatory professionals and other professionals that are part of the health network of the city regarding the operation of the devices that make up the mental health network was mentioned as a point of concern for the treatment continuation of the patient with mental disorder.

I think in the unit, they do not seek to learn about the functioning of the ambulatory [...] they refer simply without knowing [...] sometimes the patient comes here because they say 'Oh, psychiatry, just go there and they will handle it' (P3).

It was also noted that some professionals of the clinic are not aware of the activities that are developed within the service itself, for example, how the craft groups work as well as other existing projects.

[...] I don't know how this type of system works [...] I can't tell you because I don't know how it works (P2).

I know these projects, like, when we go to some event or something, they are there setting up their work [...] but I don't know the location, or the activity; one of these days I called it there, because I was doing the interview with a patient and realized that he needed to be taken care of (P5).

This lack of information is definitely a downside because there are patients who could benefit from it. I don't have the slightest idea of how it works and how to refer, I heard something about it, but I don't know much (P11).

Poor communication amongst professionals from the ambulatory was highlighted in some statements; lack of internal communication was underlined and the absence of the general meeting on the service, which could facilitate communication and exchange of information.

I miss communicating more with the psychology [...] I haven't met the psychologists yet, not even by name, we haven't been introduced [professional began to see patients in the ambulatory at the end of the year 2012] (P11).

One thing that the public service would have to change is this situation is the need to see patients, it needs to see patients [...] then stop the service one morning, get everyone together, then pass the newsletter [...] That is, to hear everyone (P9). 
The lack of interaction with other professionals in fact is a reality, the service as a whole does not speak the same language, that is, the user gets conflicting directions a few times, mainly by professionals in the UBS, Municipal Hospital (P10).

The lack of communication between the mental health network workers could be observed in a study undertaken in São Carlos (SP), in which the authors found out that the professionals barely know each other, and some are even unaware about services where they refer users to. This disruption produces losses, including the user's delay to leave CAPS to continue its treatment in the primary care as well as the mangling of the CAPS itself, which keeps users with mild to moderate disorders, or that no longer need intensive care, as a result of poor communication with other devices. ${ }^{15}$

In an evaluative study with family members, held in Porto Alegre-RS, it was shown that families would like the CAPSs to be more advertised to the society, so that they have greater visibility and inclusion within the community life. Moreover, they recognize that this modality of substitutive service is an innovation found throughout the country, aiming to de-institutionalize the subjects that were previously kept in hospital institutions. This movement of closeness and inclusion of CAPS in the community is essential for allowing users with their social reintegration, through sports activities, crafts, culture, leisure, among others. ${ }^{16}$

Reporters also mentioned the lack of meetings during service, as an important gap regarding communication, being an influential factor to the (dis) organization of the service. In a study conducted in 21 CAPSs in São Paulo-SP, the organizational activities (team meetings, organization meetings, managing council meetings and the participation in forums on mental health, for example) were not part of the activity schedule of most services, leading to believe that they were not recognized as work or that they did not receive the needed importance. ${ }^{17}$

It should be pointed out that during negotiation, there was a consensus among the professionals of the clinic about the importance of resuming general meetings for better organization of services and the discussion of patient treatment forms with the entire team. Also, according to participants, the ambulatory professionals themselves are not aware of the activities that are carried out by other workers in the service and at other points of the service network. Therefore, to overcome this issue, in addition to the team's general meetings, internal com- munication about the services must be improved, as well as different sites of attention to the person in psychic distress. More information about how the ambulatory works is also needed, in order to avoid incorrect or unnecessary referrals.

Professional turnover, especially doctors, was mentioned as a destabilizing factor for the service, given the difficulty of establishing connections.

[...] the patient has no connection with the doctor, many times I see a patient and he says 'how long are you staying here? because when a doctor arrives, he stays for six months and gets out of here' (P2).

I think the worst turnover is of the doctors, who don't stay long. Because it is an Unified Health System, they think that the pay is low, that there's a lot of hassles, that it is a place that is not really appropriate (P3).

Challenges in keeping the medical professional seems to be part of the health system itself. ${ }^{18}$ In São Paulo-SP, for example, in interviews with doctors from the ESF, the authors found that the main factors leading to the turnover involved the form of hiring, medical profile and working conditions. Correlations were also found between turnover and training, distance from healthcare facilities and availability of materials for the completion of the work..$^{18}$ About the medical turnover in ESF teams, participants concluded that this issue constituted a failure of the health system itself, and discussions with the Health Board Health of the Municipality should be held in order to be solved.

Thus, turnovers lead to the difficulty in establishing connection, considering that the interaction established between users and the health team is pointed out as a positive aspect in the construction of the mental healthcare network. ${ }^{10}$

Also in relation to turnovers, it should be noted that it is not restricted to psychiatrists in mental health services. In the city of São Carlos-SP, for example, several changes occurred in a period of six months: the psychologist and the coordinator of the Center left, a new psychologist was hired, the mental health coordinator left. ${ }^{15}$

In the negotiating meeting of this study, participants agreed that it was important for managers to reassess the recruitment policy, in order to encourage the employee to follow a public service career; and they believe that turnovers - which are rather harmful to the patient - will, thus, be lessened.

The lack of professional training and continued education was highlighted by most respondents who, in addition to requesting training and qualifi- 
cation on mental health for the ambulatory service itself, also questioned the absence of these courses and training for the UBSs staff.

I think that guidance is missing, we get here unaware of things, everyone that reads a little more ends up having a little knowledge, but if we don't go for it, there is nothing coming to us (P6).

But the ones who need training are not our employees, who already know things well, PSF are the ones in need of training (P7).

The the professional that never had experience and sometimes does not even want to have, he tends to reject, that's exactly the term, reject the patient, [...]. What are you going to do about it? Training (P12).

The problem in offering activities that qualify the professional may be related to the lack of initiatives within the perspective of SUS and the deficiency in the preparation of future professionals in higher education institutions. ${ }^{19}$

The deficit of professionals is the critical point of this network, leading to the lack of healthcare vacancies for users and, as a result, the waiting list, which results in delayed services and is one of the main problems of integrality practice. ${ }^{10}$

When examining the application of the terms of Ordinance n. 224, dated $1992,{ }^{2}$ it is noted that many professionals have started to participate in the mental health services (psychologists, nurses, social workers), but this document does not indicate how these technicians were qualified to perform their duties with the mentally ill.

What has been observed is that the implementation of expertise and training policies in mental health has been effective, in general, through partnerships that have not always worked out as expected, not resulting in greater integration between the psychosocial care and the ESF. This almost always precarious articulation causes considerable delays in the implementation of mental health policy and creates dissociation in the action of the two services. ${ }^{20}$

Therefore, it is believed that if the difficulties in the relationship with psychological distress people were minimized, and the approach/pacts with several partnerships were articulated, there would only remain problems of individual responsibility of the patients, because most of the problems attributed to patients result from the ESF limitations inserted in the healthcare network in the municipality. ${ }^{21}$

Continuous in-service education should be encouraged by SUS, as training of health professionals is configured as a challenge, considering that most of the service coordinators continue to be trained away from the debate and the construction of health policies. ${ }^{10}$ Bringing learning to the workspaces is a need felt by professionals on a daily basis. Thus, it would be essential for the relationship between the services to intensify the articulation with primary care, hospital care and replacement services as an alternative to the current strangulation of these services, in addition to allowing continuity of user's care. $^{10}$

Respondents also highlighted the professional dissatisfaction in the mental health area.

There is a large demand in the area, there are no professionals interested because of several factors: resources - either physical or structural or the encouragement for people to work in public services [...] you can neither hire nor keep the professional (P2).

Ones passes the public tender and will work there in the Child CAPS, 'Oh my God, I don't like to take care of children!' 'well, but that is your place' (P9).

When I subscribed to the tender I was required the specialist title, now I get paid the same as anyone else without a specialist title; this only lowers you (P12).

The professionals suggested the appreciation regarding the professional in two ways: firstly, through a change in the hiring form, valuing the professional relationship with the area; and secondly, through an effective career plan as working incentive. When stimulating the establishment of mental health actions, hiring of specialist professionals in the area should be a priority. ${ }^{22}$

Therefore, in the mental health as well as other areas, there is the need to review the professional recruitment manner, to improve payment and worker appreciation with the implementation of the Plan of Positions, Careers and Salaries, and to invest in the organization of the services, infrastructure, continued education and continued training of professionals, aiming at quality improvement of the services provided to the user as well as the worker's satisfaction.

\section{FINAL CONSIDERATIONS}

From the negotiation session with the professionals, it was possible to identify important weak points related to the organizational structure of the ambulatory, illustrated by the difficulty of access by users, problems in the physical structure and fragmentation of mental health services. In addition, weaknesses related to human resources have also been mentioned as, for example, the ignorance of the ambulatory professionals and others on the activities carried out by the service. 
Other highlighted points were related to the lack of training in mental health, in the form of recruitment of professionals, the lack of a career plan and the professionals' turnover, especially doctors, in the context of primary healthcare, which has hampered the collaborative work between the different points of attention in mental health in the city.

In view of the above mentioned, although the specialized ambulatories are not part of the network, according to the proposed by the Ordinance which established the Psychosocial Network within the SUS, in the current scenario of the city being studied, it still constitutes an important service within this network of assistance, for being reference for all the psychiatric care in the city. However, given the several weaknesses pointed out by professionals who work in it, their role needs to be rethought. It should be noted that, according to the professionals, in addition to the difficulties of ambulatory services, there are weaknesses throughout the whole mental health system, especially in the integration between the different levels of services.

We emphasize that this study had as its limitation the fact that it was held with a restricted population in a particular service, and it is necessary that other studies analyze the functioning and effectiveness of the ambulatories, in order to build an articulated and integrated network of assistance possible, and so that it is accessible to all who need it.

\section{REFERENCES}

1. Miranda FAN, Santos RCA, Azevedo DM, Leite RF, Costa TS. Fragmentos Históricos da Assistência psiquiátrica no Rio Grande do Norte, Brasil. Rev Gaúcha Enferm. 2010; 31(3):475-82.

2. Brasil. Portaria $n^{\circ} 224 / 92$ : estabelece diretrizes e normas para o atendimento em saúde mental. Diário Oficial da União 1992; 2 set.

3. Severo AK, Dimenstein M. Rede e intersetorialidade na atenção psicossocial: contextualizando papel do ambulatório de saúde mental. Psicol Cienc Prof. 2011; 31(3):640-55.

4. Junior JM, Nóbrega VKM, Miranda FAN. Extinção de um serviço psiquiátrico intermediário e as repercussões na atenção à saúde mental. Cienc Cuid Saude. 2011; 10(3):578-84.

5. Pereira MO, Souza JM, Costa AM, Vargas D, Oliveira MAF, Moura WN. Perfil dos usuários de serviços de saúde mental do município de Lorena - São Paulo. Acta Paul Enferm. 2012; 25(1):48-54.

6. Pereira MO, Oliveira MAF. Análise dos dispositivos de saúde mental em municípios do Vale do Paraíba. Rev Bras Enferm. 2011; 64(2):294-300.
7. Luzio CA, L'abbate S. A atenção em saúde mental em municípios de pequeno e médio portes: ressonâncias da reforma psiquiátrica. Ciênc Saúde Coletiva. 2009; 14(1):105-16.

8. Guba EG, Lincoln YS. Avaliação de Quarta Geração. Campinas (SP): Editora da Unicamp; 2011.

9. Prefeitura do Município de Maringá. Estado do Paraná. CISAM - Centro Integrado de Saúde Mental [Internet]. [cited 2012 Dec 29]. Availabe from: http:/ / www.maringa.pr.gov.br/cisam/index.php

10. Paes LG, Schimith MD, Barbosa TM, Righi LB. Rede de atenção em saúde mental na perspectiva dos coordenadores de serviços de saúde. Trab Educ Saúde. 2013; 11(2):395-409.

11. Brasil. Diretrizes para Organização das Redes de Atenção à Saúde do SUS. Grupo Técnico da Comissão Intergestores Tripartite. Versão/dezembro 2010 [cited 2013 Nov 15]. Availabe from: http:/ / portal.saude.gov. $\mathrm{br} /$ portal/arquivos/pdf/2b_221210.pdf

12. Lucchese R, Oliveira AGB, Conciani ME, Marcon SR. Saúde mental no Programa Saúde da Família: caminhos e impasses de uma trajetória necessária. Cad Saúde Pública. 2009; 25(9):2033-42.

13. Quindere PHD, Jorge MSB. (Des)construção do modelo assistencial em saúde mental na composição das práticas e dos serviços. Saude soc. 2010; 19(3):569-83.

14. Nascimento AF, Galvanese ATC. Avaliação da estrutura dos centros de atenção psicossocial do município de São Paulo, SP. Rev Saúde Pública. 2009; 43(Supl1):8-15.

15. Dobies DV, Fioroni LN. A assistência em saúde mental no município de São Carlos/SP: considerações sobre a história e a atualidade. Interface, Comunic Saúde Educ. 2010; 14(33):285-99.

16. Camatta MW, Nasi C, Adamoli NA, Kantorski LP, Schneider JF. Avaliação de um centro de atenção psicossocial: o olhar da família. Ciênc Saúde Coletiva. 2011; 16(11):4405-14.

17. Zerbetto SE, Efigênio EB, Santos NLN, Martins SC. O trabalho em um Centro de Atenção Psicossocial: dificuldades e facilidades da equipe de enfermagem. Rev Eletr Enf [Internet]. 2011 [cited 2013 Nov 15]; 13(1):99-109. Available from: http://dx.doi. org/10.5216/ree.v13i1.9079.

18. Campos CVA, Malik AM. Satisfação no trabalho e rotatividade dos médicos do Programa de Saúde da Família. Rev Adm Pública. 2008; 42(2):347-68.

19. Munari DB, Melo TS, Pagotto V, Rocha BS, Soares CB, Medeiros M. saúde mental no contexto da atenção básica: potencialidades, limitações, desafios do Programa Saúde da Família. Rev. Eletr Enf [Internet]. 2008 [cited 2013 Nov 15]; 10(3):784-95. Available from: http://www.fen.ufg.br/revista/v10/n3/ v10n3a24.htm

20. Oliveira AGB, Conciani ME, Marcon SR. A capacitação e a gestão de equipes do PSF para a atenção 
psicossocial: um estudo de caso. Cienc Cuid Saude. 2008; 7(3):376-84.

21. Amarante AL, Lepre AS, Gomes JLD, Pereira AV, Dutra VFD. As estratégias dos enfermeiros para o cuidado em saúde mental no programa saúde da família. Texto Contexto Enferm. 2011; 20(1):85-93.
22. Onocko-Campos RT, Gama CA, Ferrer AL, Santos DVD, Stefanello S, Trapé TL, Porto K. Saúde mental na atenção primária à saúde: estudo avaliativo em uma grande cidade brasileira. Ciênc Saúde Coletiva. 2011; 16(12):4643-52. 